\title{
Pengaruh Word of Mouth dan Sales Promotion terhadap Keputusan Pembelian (Survei terhadap Produk CV. Anugrah Kencana Makmur)
}

\author{
Angga Budiman', Rezi Erdiansyah ${ }^{2 *}$ \\ ${ }^{1}$ Fakultas Ilmu Komunikasi, Universitas Tarumanagara \\ Email: anggabudiman97@gmail.com \\ ${ }^{2}$ Fakultas Ilmu Komunikasi, Universitas Tarumanagara* \\ Email: rezie@fikom.untar.ac.id
}

Masuk tanggal : 15-12-2021, revisi tanggal :06-01-2022, diterima untuk diterbitkan tanggal : 16-01-2022

\begin{abstract}
Marketing communication is a marketing activity aimed at disseminating information, influencing or persuading. There are many forms of marketing communication that companies use, one of which is word of mouth and Sales Promotion. Word of mouth is a consumer activity in providing information to others about a brand or product. In addition to word of mouth, purchasing decisions are also influenced by marketing strategies. Sales promotion is a tool used by companies to increase the level of sales of a product and create repeat purchases or create loyalty. Both are factors that influence consumer decisions to consider product purchases. This research was conducted using quantitative techniques with survey methods and made a questionnaire as a research instrument. Primary data was collected through the distribution of questionnaires to 110 respondents who were customers of CV. Anugrah Kencana Prosperous. The data is processed with the help of SPSS software for windows version 25. According to the results of the study, there is a positive influence between word of mouth and sales promotion on purchasing decisions. Word of mouth and sales promotion have an influence of $80.7 \%$ on purchasing decisions, so it can be interpreted that word of mouth and sales promotion have a major influence on purchasing decisions.
\end{abstract}

Keywords: purchasing decisions, sales promotion, word of mouth

\begin{abstract}
Abstrak
Komunikasi pemasaran merupakan aktivitas pemasaran yang bertujuan menyebarkan informasi, memengaruhi atau mempersuasi. Ada banyak bentuk komunikasi pemasaran yang perusahaan gunakan, salah satunya adalah informasi dari mulut ke mulut atau Word of Mouth dan Sales Promotion. Word of mouth adalah aktivitas konsumen dalam memberikan informasi kepada orang lain tentang suatu merek atau produk. Selain word of mouth, keputusan pembelian juga dipengaruhi oleh strategi pemasaran. Sales promotion merupakan alat yang digunakan perusahaan untuk menaikkan tingkat penjualan suatu produk serta meciptakan pembelian yang berulang atau menciptakan loyalitas. Keduanya merupakan faktor yang memengaruhi keputusan konsumen untuk mempertimbangkan pembelian produk. Penelitian ini dilakukan dengan menggunakan teknik kuantitatif dengan metode survei dan menjadikan angket sebagai istrumen penelitian. Data primer dikumpulkan melalui pembagian kuesioner kepada 110 responden yang dimana adalah pelanggan dari CV. Anugrah Kencana Makmur. Data diolah dengan bantuan software SPSS for windows versi 25. Menurut hasil penelitian, ada pengaruh positif antara word of mouth dan sales promotion terhadap keputusan pembelian. Word of Mouth dan Sales Promotion memiliki pengaruh sebesar $80,7 \%$ terhadap keputusan pembelian, maka dengan demikian dapat diartikan bahwa word of mouth dan sales promotion memiliki pengaruh yang besar terhadap keputusan pembelian.
\end{abstract}


Kata kunci: keputusan pembelian, sales promotion, word of mouth

\section{Pendahuluan}

Teknologi yang berkembang dengan pesat menciptakan inovasi dalam bidang bisnis. Satu-satunya proses yang dapat menghubungkan perusahaan dengan para konsumennya adalah komunikasi, baik secara verbal maupun nonverbal. Komunikasi yang dilakukan perushaan terhadap konsumennya adalah menawarkan suatu produk ataupun jasa dengan tujuan untuk mempengaruhi keputusan pembelian konsumen atas produk dan jasa yang ditawarkan oleh suatu perusahaan.

Komunikasi seperti ini disebut komunikasi pemasaran. Menurut Tjiptono, komunikasi pemasaran mengacu pada aktivitas pemasaran yang bertujuan untuk menyebarkan informasi, mempengaruhi atau mempersuasi dan mengingatkan objek sasaran produknya untuk memahami, membeli, dan setia kepada produknya (Notowijoyo dan Loisa, 2020).

Ada banyak bentuk komunikasi pemasaran yang perusahaan gunakan, salah satu bentuk contoh komunikasi pemasaran yang sering kita lihat adalah informasi dari mulut ke mulut atau Word of Mouth dan Sales Promotion. Menurut WOMMA (Word Of Mouth Marketing Association) Word of mouth adalah aktivitas dimana konsumen memberikan informasi kepada orang lain tentang suatu merek atau produk. Jika tidak menyadarinya, pelanggan yang telah membeli dan menggunakan produk tersebut akan menceritakan pengalamannya tanpa disadari bahwa itu berarti mereka telah melakukan aktivitas promosi dari mulut ke mulut (Julianti dan Junaidi, 2020).

Selain word of mouth, keputusan pembelian juga dipengaruhi oleh strategi pemasaran. Salah satu strategi pemasaran yang terkenal juga adalah sales promotion. Sales promotion merupakan alat yang digunakan perusahaan untuk menaikkan tingkat penjualan suatu produk serta meciptakan pembelian yang berulang atau menciptakan loyalitas (Nelviluvita dan Oktavianti, 2019). Keduanya merupakan salah satu faktor yang mempengaruhi keputusan konsumen untuk mempertimbangkan pembelian produk. Keputusan pembelian merupakan proses menggabungkan pemahaman untuk mengulas dua atau lebih perilaku alternatif dan menentukan salah satunya. Keputusan yang dibuat oleh konsumen bisa dipahami sebagai pemecahan masalah. Dalam proses pengambilan keputusan, konsumen menentukan tujuan atau perilaku untuk mencapai tujuan tersebut. Perilaku ini dapat membantu menyelesaikan masalahnya (Peter dan Olson, Setiadi dalam Tehuayo, 2018). Berdasarkan penjelasan latar belakang tersebut, peneliti tertarik untuk melihat apakah ada pengaruh antara word of mouth dan sales promotion terhadap keputusan pembelian.

\section{Metode Penelitian}

Pada penelitian ini bermaksud untuk melihat pengaruh word of mouth dan sales promotion terhadap keputusan pembelian. Penelitian ini menggunakan metode penelitian kuantitatif dengan teknik survei. Metode survei merupakan suatu penelitian yang mengumpulkan data atau informasi dengan cara menyampaikan list pertanyaan atau pernyataan kepada responden. Penggalian data dapat dilakukan melalui kuesioner dan wawancara (Sujarweni, 2019). Populasi merupakan suatu kawasan umum yang terdiri dari objek dengan karakteristik tertentu yang telah 
ditentukan oleh peneliti untuk dikaji, dianalisis, dan ditarik kesimpulannya. (Sugiyono, 2017). populasi yang diteliti oleh penulis adalah seluruh masyarakat daerah Palembang yang mengetahui CV. Anugrah Kencana Makmur.

Sampel merupakan bagian dari banyak karakteristik populasi yang digunakan untuk penelitian. Jika populasinya besar, maka tidak mungkin peneliti menggunakan semuanya untuk penelitian, mungkin karena adanya keterbatasan dana, energi dan waktu, maka dari itu penulis dapat menggunakan sampel yang diperoleh dari populasi tersebut. Kesimpulan yang dipahami dari sampel akan diaplikasikan pada populasi (Sujarweni, 2019).

Menurut Charvia dan Erdiansyah (2020), Untuk menentukan jumlah sampel dalam penelitian, banyaknya responden yang digunakan untuk penelitian bergantung pada banyaknya jumlah indikator penelitian dikali 5. Dalam penelitian ini, peneliti menyebarkan kuesioner kepada 110 responden yang merupakan masyarakat daerah Palembang yang menjadi konsumen atau pelanggan dari CV. Anugrah Kencana Makmur. Penyebaran kuesioner dilakukan melalui google form untuk memperoleh data yang cocok dengan harapan peneliti. Penelitian ini memakai metode purposive sampling yang merupakan teknik yang dipakai dengan menetapkan kriteria spesifik terhadap sampel. Penelitian ini diukur dengan skala likert kemudian diolah menggunakan software SPSS versi 25 untuk menguji validitas, reliabilitas, korelasi, dan hipotesis.

\section{Hasil Temuan dan Diskusi}

Dalam kasus ini, peneliti membagikan kuesioner kepada 110 responden dan mendapatkan data berupa jenis kelamin. Sebanyak 53 orang $(48,2 \%)$ responden berjenis kelamin laki-laki dan 57 orang $(51,8 \%)$ responden berjenis kelamin perempuan. Setelah melakukan uji validitas dengan menggunakan aplikasi SPSS for windows versi 25, maka berikut hasil dari uji validitas.

Dalam hasil uji validitas, diketahui bahwa butir-butir indikator atau pernyataan dari seluruh variabel dinyatakan valid karena seluruhnya memiliki nilai diatas 0,2. Kemudian dalam hasil uji reliabilitas, diketahui bahwa setiap pernyataan dalam kuisoner dikatakan reliabel karena memiliki nilai Cronbach's Alpha di atas 0,6. Nilai Cronbach's Alpha untuk word of mouth adalah 0,722, kemudian untuk sales promotion adalah 0,851 , dan untuk keputusan pembelian adalah 0,901. Dan dalam penelitian ini, peneliti menggunakan uji One Sample Kolmogorov Smirnov yang ada pada aplikasi SPSS Ver 25. Hasil analisis menunjukan bahwa ada nilai signifikansi sebesar 0,097. Hasil ini menyatakan bahwa distribusi data berdistribusi secara normal karena nilai signifikansi $>0,05$.

Tabel 1. Uji T

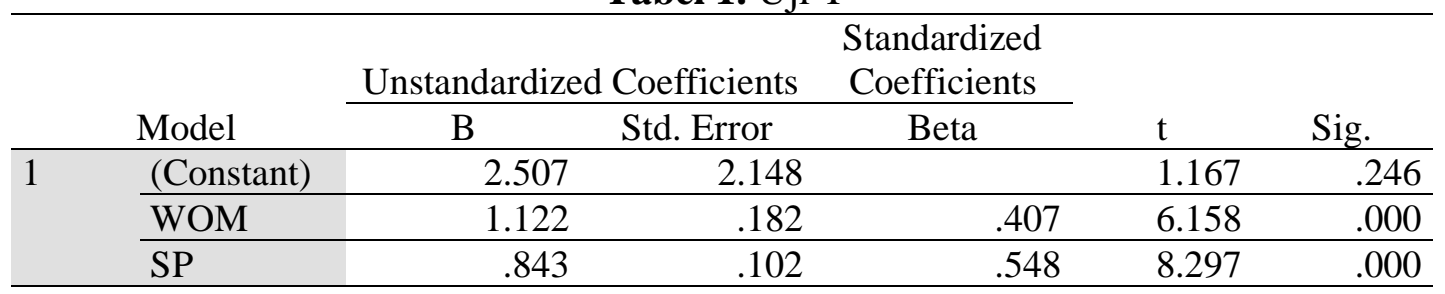

Sumber: Hasil Pengolahan Data SPSS Versi 25 
Tabel 1 menunjukkan dari hasil analisis data diketahui bahwa nilai t untuk word of mouth $=6,158$ sementara untuk nilai $\mathrm{t}$ sales promotion $=8,297$. Tingkat signifikansi keduanya adalah $=0,00<0,05$. Karena nilai $\mathrm{p}$ lebih kecil dari 0,05, maka $\mathrm{H}_{0}$ ditolak dan $\mathrm{H}_{1}$ dan $\mathrm{H}_{2}$ diterima, yang berarti terdapat pengaruh yang signifikan antara word of mouth dan sales promotion terhadap keputusan pembelian.

Tabel 2. Uji Regresi Linear Berganda

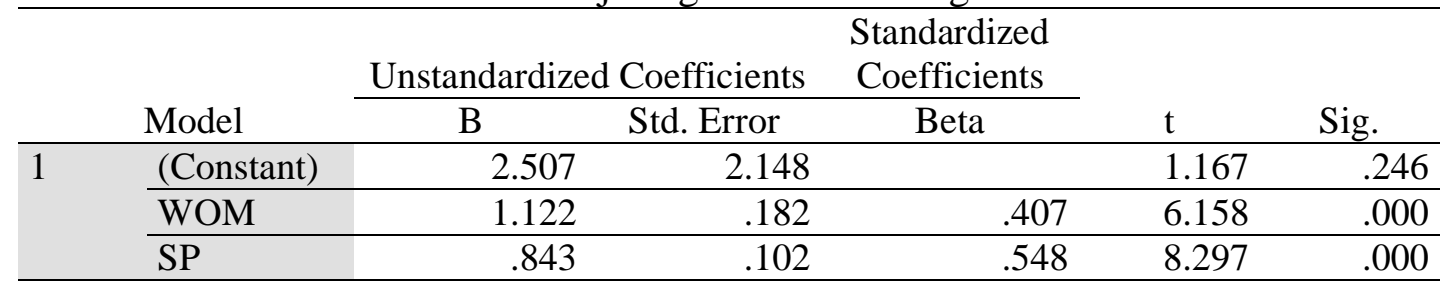

Sumber: Hasil Pengolahan Data SPSS Versi 25

Dengan keterangan $\mathrm{Y}=$ keputusan pembelian dan $\mathrm{X}_{1}=$ word of mouth dan $\mathrm{X}_{2}$ $=$ sales promotion. Berdasarkan persamaan regresi linear pada tabel 5, dapat diartikan nilai sebesar 2,507 menyatakan konstanta dari fungsi regresi yang menunjukkan bahwa jika tidak ada kenaikan variabel $\mathrm{X}_{1}$ (Word of Mouth) dan $\mathrm{X}_{2}$ (Sales Promotion), maka variabel Y (Keputusan Pembelian) akan tetap di 2,507. Setiap ada penambahan 1 satuan pada variabel $\mathrm{X}_{1}$ (Word of Mouth), maka variabel Y (Keputusan Pembelian) akan mengalami peningkatan sebesar 1,122 dan setiap ada penambahan 1 satuan pada variabel $\mathrm{X}_{2}$ (Sales Promotion), maka variabel $\mathrm{Y}$ (Keputusan Pembelian) akan mengalami peningkatan sebesar 0,843.

Tabel 3. Hasil Uji Korelasi

\begin{tabular}{ccccc}
\hline Model & $\mathrm{R}$ & $\mathrm{R}$ Square & $\begin{array}{c}\text { Adjusted R } \\
\text { Square }\end{array}$ & $\begin{array}{c}\text { Std. Error of } \\
\text { the Estimate }\end{array}$ \\
\hline 1 & $.898^{\mathrm{a}}$ & .807 & .803 & 2,54881 \\
\hline
\end{tabular}

Sumber: Hasil Pengolahan Data SPSS Versi 25

Dari hasil perhitungan tabel 3 , didapati bahwa nilai koefisien korelasi $\mathrm{R}$ sebesar 0,898 yang berada di antara interval 0,80-0,100 artinya word of mouth dan sales promotion mempunyai hubungan yang sangat kuat terhadap keputusan pembelian.

Tabel 4. Hasil Uji Determinasi

\begin{tabular}{ccccc}
\hline Model & $\mathrm{R}$ & $\mathrm{R}$ Square & $\begin{array}{c}\text { Adjusted R } \\
\text { Square }\end{array}$ & $\begin{array}{c}\text { Std. Error of } \\
\text { the Estimate }\end{array}$ \\
\hline 1 & $.898^{\mathrm{a}}$ & .807 & .803 & 2,54881 \\
\hline
\end{tabular}

Sumber: Hasil Pengolahan Data SPSS Versi 25

Dari hasil perhitungan tabel 4, didapati nilai pada tabel $\mathrm{R}$ Square sebesar 0,807 mengartikan bahwa 80,7\% keputusan pembelian dipengaruhi oleh word of mouth dan sales promotion. Sementara sisanya 19,3\% (100\%-80,7\%) dipengaruhi oleh faktor lain.

Secara keseluruhan hasil dari penelitian ini menggambarkan adanya pengaruh antara word of mouth dan sales promotion terhadap keputusan pembelian. Hal ini ditunjukkan dengan hipotesis dalam penelitian diterima, artinya bahwa ada pengaruh positif antara word of mouth dan sales promotion terhadap keputusan pembelian. Hal 
itu ditunjukkan pada hasil uji regresi linear sederhana yang dimana nilai koefisien regresi bernilai positif. Menurut Julanti \& Junaidi (2020), Jika konsumen yang membeli dan memakai produk ini menceritakan tentang pengalaman mereka, tetapi tidak menyadarinya, itu berarti mereka telah melakukan aktivitas word of mouth. Sebagian besar responden setuju dan sangat setuju mengenai konsumen sering mendengar produk atau merek tertentu dibicarakan oleh keluarga, teman, ataupun orang lain, dengan persentase sebesar 50.9\% untuk setuju dan 46,4\% untuk sangat setuju. Salah satu alat komunikasi pemasaran yang paling dikenal adalah sales promotion. Sales promotion merupakan alat yang digunakan perusahaan untuk menaikkan tingkat penjualan suatu produk serta meciptakan pembelian yang berulang atau menciptakan loyalitas (Nelviluvita \& Oktavianti (2019).

Dari analisis hasil penelitian diketahui bahwa sebanyak $49,1 \%$ dan $46,4 \%$ dari jumlah responden memilih setuju dan sangat setuju mengenai konsumen sering menggunakan kupon untuk berbelanja. Ini menunjukkan bahwa konsumen merasa diuntungkan dengan adanya kupon dan memutuskan untuk berbelanja lagi karena adanya kupon atau reward tersebut.

Menurut Assauri (Geraldine dan Candraningrum, 2020), keputusan pembelian merupakan proses pengambilan keputusan pembelian, termasuk menentukan apa yang akan dibeli atau tidak, dan keputusan tersebut didapat dari aktivitas sebelumnya. Sebagian besar responden setuju dan sangat setuju mengenai konsumen membeli produk dari perusahaan karena mengenal merek ataupun perusahaan tersebut, dengan persentase sebesar $49,1 \%$ untuk setuju dan $49,1 \%$ untuk sangat setuju.

Dengan adanya word of mouth mengenai produk dari CV. Anugrah Kencana Makmur dan sales promotion yang dilakukan oleh CV. Anugrah Kencana Makmur, masyarakat di daerah palembang menjadi lebih mengetahui tentang produk dari CV. Anugrah Kencana Makmur, sehingga akan meningkatkan keputusan pembelian dan loyalitas masyarakat terhadap pembelian yang bersangkutan dengan produk dari CV. Anugrah Kencana Makmur.

\section{Simpulan}

Penelitian ini menyimpulkan bahwa word of mouth dan sales promotion terhadap keputusan pembelian memiliki hubungan yang sangat kuat. Berdasarkan hasil uji korelasi, diketahui bahwa nilai korelasi berada di interval 0,80 - 0,100 yang berarti word of mouth dan sales promotion memiliki peranan yang sangat kuat terhadap keputusan pembelian dan bersifat positif. Kemudian dari hasil determinasi menunjukkan bahwa word of mouth dan sales promotion memiliki peranan sebesar $80,7 \%$ terhadap keputusan pembelian. Sementara sisanya 19,3\% (100\%-80,7\%) dipengaruhi oleh faktor lain. Dengan demikian, semakin tinggi suatu word of mouth dan sales promotion maka keputusan pembelian juga akan meningkat. Begitu juga sebaliknya, semakin rendah suatu word of mouth dan sales promotion maka keputusan pembelian juga akan semakin menurun.

Berdasarkan kuesioner yang telah disebarkan, data pernyataan sebanyak 22 butir pernyataan dikatakan valid, karena semua pernyataan yang telah disebarkan memiliki nilai diatas 0,2 dan mendukung hipotesis bahwa ada pengaruh yang kuat antara word of mouth dan sales promotion terhadap keputusan pembelian. 


\section{Ucapan Terima Kasih}

Ucapan terima kasih diberikan kepada Fakultas Ilmu Komunikasi Universitas Tarumanagara, responden penelitian, keluarga, teman-teman, dan seluruh pihak yang membantu peneliti dalam menyempurnakan penelitian ini.

\section{Daftar Pustaka}

Julianti, Dini Anindya \& Junaidi, Ahmad. (2020). Pengaruh Word Of Mouth Terhadap Keputusan Pembelian Baso Aci Akang Citra Raya Tangerang. Prologia. Vol.4 No.1, 75-81.

Nelviluvita \& Oktavianti, Roswita. (2020). Pengaruh Komunikasi Sales Promotion Terhadap Loyalitas Pengguna Aplikasi Transportasi Online (Survei pada Pengguna Grab Bike). Prologia. Vol. 3 No.2, 464-472.

Notowijoyo, Edwin \& Loisa, Riris. (2020). Analisis Komunikasi Pemasaran Go-pay Melalui Promosi Cashback. Prologia. Vol.4 No.2, 332-338.

Sugiyono. (2017). Metode Penelitian Kuantitatif, Kualitatif, dan R\&D. Bandung: Alfabeta.

Sujarweni, Wiratna. (2019). Metodologi Penelitian. Yogyakarta: PT. Pustaka Baru.

Tehuayo, Erlinda. (2018). Analisis Proses Pengambilan Keputusan Konsumen Pada Perilaku Pembelian Produk Yamaha Mio Di Kota Ambon. Jurnal SOSOQ. Vol 6 No. 2, 25-34. 